\title{
Review Studies On Bio-Diesel Production From Physic Nut (Jatropha Curcus) Oil
}

\author{
Dhanapal Venkatachalam ${ }^{*}$, Samuel Thavamani B' ${ }^{\mathbf{1}}$, Alphy Joseph ${ }^{\mathbf{1}}$ \\ 1.Department of Pharmacognosy, Sanjo College of Pharmaceutical Studies, Velappara, \\ Palakkad, Kerala - 678702.
}

\begin{abstract}
Jatropha curcus belonging to the Family, Euphorbiaceous commonly known as physic nuts. It is well known herb all over the world. J.curcas oil is not edible and is traditionally used for manufacturing soap and other medicinal applications. It is an alternative fuel for diesel engines. This review is based on focusing on the biodiesel production from the plant Jatropha curcas. Production of Biodiesel from Jatropha curcas seed oil involved three steps include extraction of oil from the seed, acid-catalyzed transesterification, and base-catalyzed transesterification, each of which is well-known and widely-utilized in today's biodiesel industry The produced bio diesel was characterized to obtain its physicochemical parameters such as flash point, pour point, cloud point, viscosity and density. The results obtained from the calculation of the yield of oil extracted revealed $54 \%$ of oil could be obtained from the Jatropha seeds used. According to the results, the values obtained from the analysis of the oil especially free fatty acid, density and kinematic viscosity of the oil were found to compare well with the standard (ASTM), which was an indication that the extracted oil was good and suitable for biodiesel production The considered parameters oil content, iodine value, peroxide value, saponification value and acid value. These parameters were done in order to study the oil property of $J$ curcas L which makes the oil most suitable for biodiesel production. In these reveals that biodiesel has become more attractive as an alternative to fossil diesel because of its environmental benefits and the fact that it is made from renewable resource. J. curcas L. is a promising source of biodiesel since its seeds contain high amount of oil and the species has good agronomic traits.
\end{abstract}

Keywords: Jatropha curcus, Biodiesel production, physiochemical parameters. 


\section{INTRODUCTION}

Jatropha curcas L. or physic nut is a drought resistant large shrub or small tree, belonging to the genus Euphorbiaceae, producing oil containing seeds (Jongschaap et al, 2007). Jatropha curcas L. is the commonest specie found in India, but many species exist in different parts of the world. Heller,(1996) reported about 165-175 species that were known from the genus Jatropha Bhagat and Kulkarni(nd) report 14 wild and cultivated species in India. Jatropha is suitable for quick and efficient domestication compared with other woody species (Achten, et al, 2010). Names used to describe the plant vary per region or country. It is most commonly known as 'Physic nut". In Mali it is known as "Pourghere". Unlike the major oil seed crops, there are currently no agronomically improved varieties available for J. curcas. At present, the varieties being used to established plantations in Africa and Asia are inedible (King et al,2009) Due to its toxicity, J.curcas oil is not edible and is traditionally used for manufacturing soap and medicinal applications (Jongschaap et al, 2007).

Due to the fact that the seeds of J.curcas contains some toxins compounds such as those reported by (King et al, 2009) a protein (curcin) and phorbol-esters (diterpenoids), other researchers (Goel, et al,2007) suggested that the detoxification or complete removal of phorbol esters is essential before its use in industrial or medicinal applications.

Biodiesel production is one of the current areas of research in academics because of the serious search for alternative effect of temperature and mixing rate variation on biodiesel production from Jatropha using sodium hydroxide catalyst and methanol. In the work, high temperature and high mixing intensity were found to increase the rate constants of the process best combination of the parameters for production of biodiesel from Jatropha curcas were 6:1 molar ratio of methanol to oil, $0.92 \% \mathrm{NaOH}$ catalyst, $60 \mathrm{oC}$ reaction temperature and $60 \mathrm{~min}$ of reactionel from Jatropha curcas seed oil using potassium hydroxide catalysed transesterification process ${ }^{1}$. In order to achieve this aim, extraction of the oil from Jatropha curcas seed using solvent extraction method, Then the oil from Jatropha curcas is mainly converted into biodiesel for use in diesel engines ${ }^{2}$ The cake resulting from oil extraction, a protein-rich product, can be used for fish or animal feed (if detoxified). It is also a biomass feedstock to power electricity plants or to produce biogas, and a high-quality organic fertilizer ${ }^{3}$ In 2007, Goldman Sachs cited Jatropha curcas as one of the best candidates for future biodiesel production. It is resistant to drought and pests, and produces seeds containing $27-40 \%$ oil, averaging $34.4 \%$. The remaining press cake of jatropha seeds after oil extraction could also be considered for energy production. However, 
despite their abundance and use as oil and reclamation plants, none of the Jatropha species have been properly domesticated and, as a result, their productivity is variable, and the long-term impact of their large-scale use on soil quality and the environment is unknown ${ }^{4} 2009$ research found that Jatropha biodiesel production requires significantly more water than other common bio fuel crops, and that initial yield estimates were high ${ }^{5}$

This paper attempts to review the production of biodiesel from the seeds of Jatropha curcus.

Plant profile:
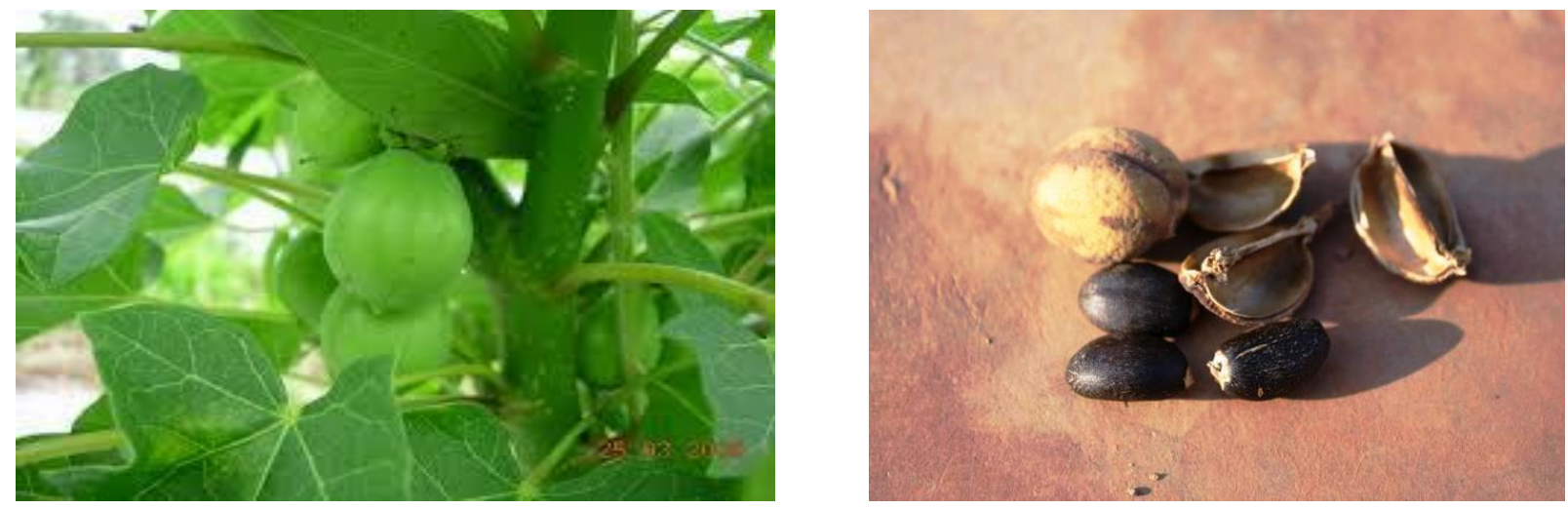

Figure 1- Jatropha curcus plant with unripe fruit Figure 2- Fresh seeds of Jatropha curcus

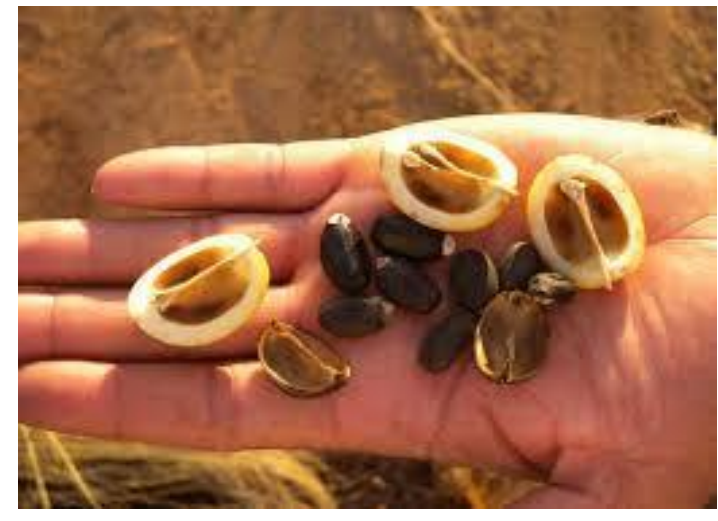

Figure 3- Seeds of Jatropha curcus

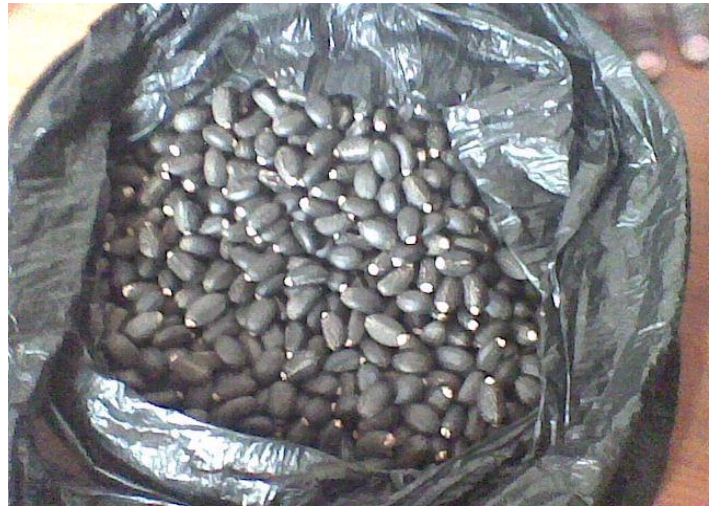

Figure 4- Dried seeds of Jatropha curcus

The origin of Jatropha curcas and the Countries that are prominent in growing the plant:

Jatropha curcas originates from central America and was distributed by Portuguese seafarers via the cape Verde Islands to countries in Africa and Asia .(Hernning,2003). Jatropha is widely grown in Mexico,Nicaragua, N.E.Thailand and in parts of India.

\section{Chemical Composition of Jatropha curacas L.}

\section{Seed:}

The seeds contain around $20 \%$ saturated fatty acids and $80 \%$ unsaturated fatty acids, and they yield $25-40 \%$ oil by weight. In addition, the seeds contain other chemical compounds, such as 
saccharose, raffinose, stachyose, glucose, fructose, galactose, and protein. The oil is largely made up of oleic and linoleic acids. Furthermore, the plant also contains curcasin, arachidic, myristic, palmitic, and stearic acids and curcin.

\section{Seed Husks}

Seed kernel contains predominantly crude fat oil and protein while the seed coat (husk) contains mainly fibre.

\section{Seed Cake}

Seed cake makes an excellent organic fertilizer with high nitrogen content similar to, or better than, chicken manure with macronutrient contents such as Nitrogen\% (4.4-6.5), P\% (2.1-3.0), $\mathrm{K} \%(0.9-1.7), \mathrm{Ca} \%(0.6-07)$ and $\mathrm{Mg} \%$ (1.3-1.4) seed cake contains mainly proteins and carbohydrates.

\section{Seed Oil}

Jatropha seed oil chemically consists of triacylglycerol with linear fatty acid chain (unbranched) with/without double bonds.

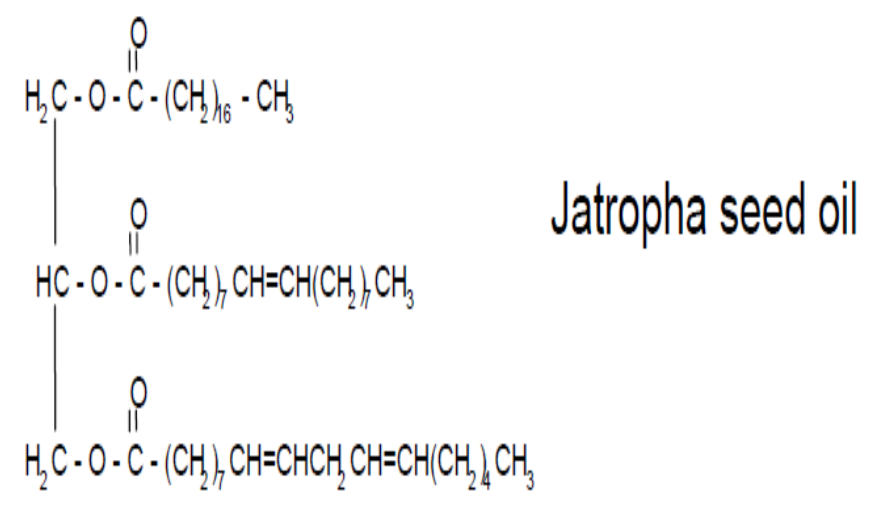

\section{Biodiesel production from seed oil of the Jatropha curcas plant}

The production of biodiesel from Jatropha Curcas seeds were comprised of three major steps:

1. Extraction of seed oil: A solvent extraction method is used to extract the oil from crushed Jatropha seed flakes.

2. Treatment of seed oil: The free fatty acid content in the seed oil is reduced by acid-catalyzed transesterification to give a higher biodiesel yield product in the third and final step.

3. Conversion of seed oil to biodiesel: This step utilizes base- catalyzed transesterification process which effectively produces biodiesel from the treated Jatropha Curcas seed oil ${ }^{6}$

Extraction of oil from Jatropha seeds: 


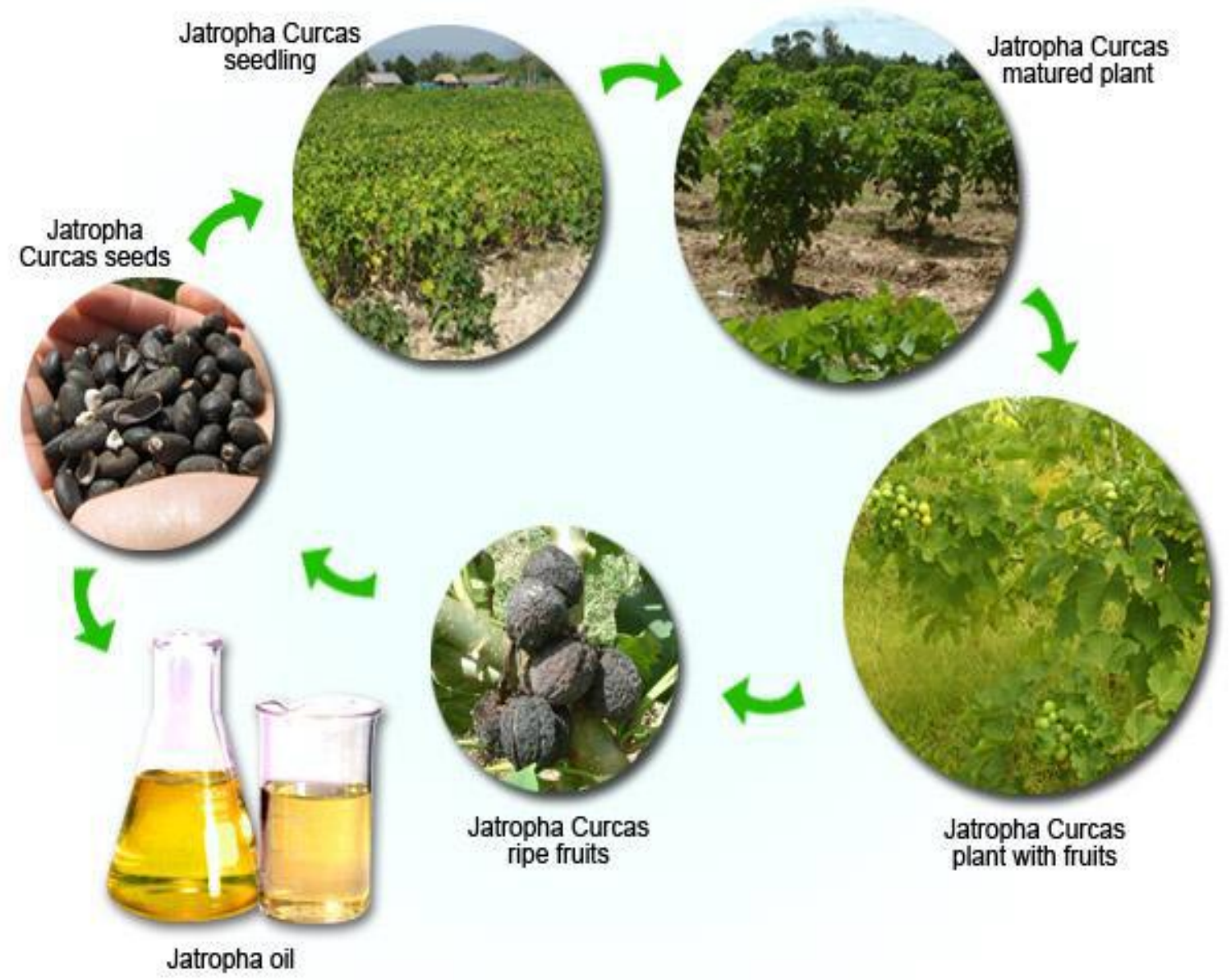

In preparation for oil extraction from the Jatropha seeds, they (the seeds) were sun dried, shelled and weighed. After then, they were sun dried again, ground and the weight of the ground seeds was taken. Solvent extraction method, using n-hexane as the solvent, was employed in extracting the oil from the ground seed meal. The choice of n-hexane as the extraction solvent was owing to the fact that it is non-poisonous and volatile with high affinity for oil. Besides, it can be easily recovered. At the end of oil extraction, the extract was filtered and the solvent was recovered using a rotary evaporator. The oil was further evaporated in an oven at $105^{\circ} \mathrm{C}$ to eliminate residual solvent and moisture content. The percentage yield was then calculated using the relationship given in the following Equation $^{7}$

$\%$ Yield $=\%$ Weight of sample / Weight of oil 100 


\section{Processing for Oil Extraction by Mechanical method}

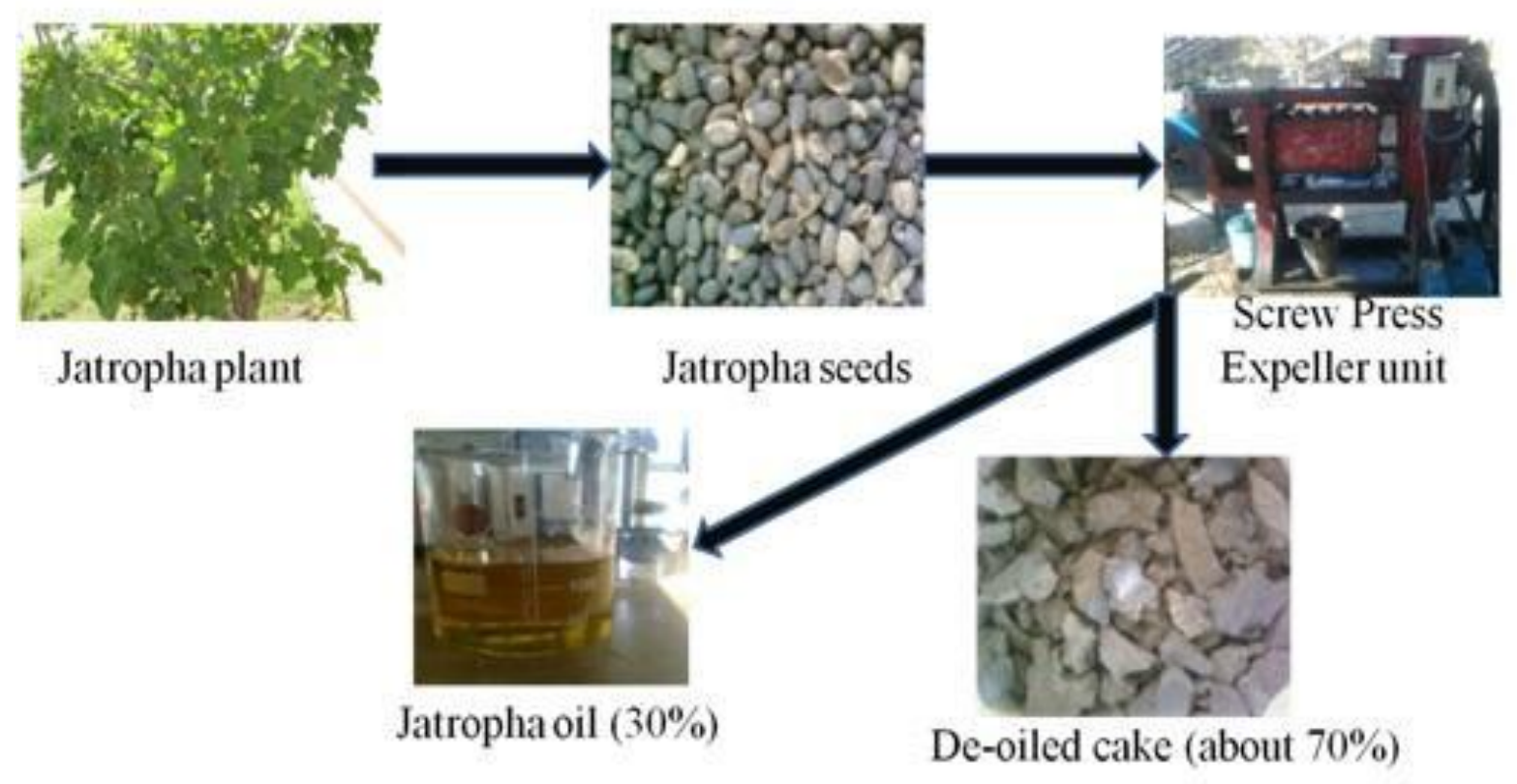

\section{Figure : Collection, drying and extraction of jatropha seeds}

\section{Extraction of Seed Oil Alternatives}

Alternatives methods for extracting the oil with in Jatropha seeds include mechanical pressing and ultrasonification. Of these, mechanical pressing with either manual or electrical power is most common. This technique lacks in efficiency, though, as only 50-60\% of the oil is able to be extracted from the seed husks. Also, heat generated during pressing of the oil and reduces the overall quality and yield. Ultra sonification, another method considered, entire the use of highintensity acoustic energy and specialty equipment. The chosen method, solvent extraction, utilizes a solvent to extract oil from the seed husks. Many chemicals can serve as the solvent for this process, including hydrocarbon solvents like hexane, halogenated solvents like trichloroethylene, and supercritical solvents such as supercritical $\mathrm{CO}_{2}$. Hexane was chosen as the best solvent for this process due to two favorable characteristics - an extraction grade of 48-98\% and a narrow distillation range ${ }^{8}$

\section{Determination of the Characteristics of the Oil}

The oil extracted from the Jatropha seeds was characterized and its physicochemical parameters such as acid value, saponification value, Iodine value, free fatty acids, density and kinetic 
viscosity were determined by official methods ${ }^{9-13}$. It results showed to be sure that it would be suitable for biodiesel production.

Acid value - $(\mathrm{mgKOH} / \mathrm{g})-4.77$

Saponification value - $(\mathrm{mgKOH} / \mathrm{g})$ - 115.83

Iodine value- $(\mathrm{mEq} / \mathrm{g})$ - 119.1

Free fatty acid - $(\mathrm{mgKOH} / \mathrm{g})-2.3$

Density - (g/cm3) - 0.874

Kinematic viscosity - (cm3/s) - 4.57

\section{Process description for biodiesel production:}

As previously mentioned the proposed method for biodiesel production requires three main steps. These steps include hexane solvent extraction, acid-catalyzed transesterification, and basecatalyzed transesterification, each of which is well-known and widely-utilized in today's biodiesel industry. These steps also allow for a high yield of the final biodiesel product, the primary goal of process optimization, and each has been classified into one of four areas of the resulting simulation. Extraction of seed oil via hexane solvent extraction takes place in Area 100, treatment and conversion via transesterification occurs in Area 300, and biodiesel treatment and methanol recovery take place in Area 400. Hexane recovery, another important step, occurs in Area 200. Simulation of this process was based on an annual biodiesel production of two million gallons $^{14}$

\section{Biodiesel Production}

Transesterification process, which is the process of converting extracted oil into biodiesel, was carried out in this work by reacting the extracted Jatropha oil with methanol in the presence of potassium hydroxide as a catalyst to produce ester and glycerol. At the end of the reaction, glycerol and biodiesel formed two layers. After settling, the glycerol was at the bottom while the biodiesel was at the top of the container used. The layers were later separated from each other by draining the glycerol from the bottom of the flask containing the mixture. The initial triglyceride content of the oil was determined by titrimetric analysis. Keeping reaction temperature and stirring rate constant at $65^{\circ} \mathrm{C}$ and $460 \mathrm{rpm}$ respectively, three different biodiesel production conditions were varied. Firstly, transesterification was done keeping the molar ratio of oil to methanol at $4: 1$ and $2.5 \%$ catalyst concentration and varying reaction time. Secondly, keeping the reaction time at 75 minutes, 4:1 molar ratio and varying the catalyst load, another set of biodiesel was produced. Thirdly, the methanol to oil molar ratio was varied while keeping constant the reaction time at $75 \mathrm{~min}$ and the catalyst concentration at $2.5 \%$. Thereafter, another 
biodiesel production was carried out using the obtained optimum parameters from the investigations carried out before, and the yield of that was determined by titrimetric analysis and appropriate calculations ${ }^{15}$

\section{Design Alternatives}

There are several design alternatives for the production of biodiesel from Jatropha curcas seed oil. Alternatives for the main steps of the production process are as follows ${ }^{16}$

\section{Treatment of Seed Oil and Conversion of Seed Oil to Biodiesel Alternatives}

Biodiesel production process was designed as follows, beginning with the extraction of the raw seed oil. First, raw Jatropha Curcas seeds are crushed in a grinder. The Jatropha curcas oil (JCO) is then removed from the seed flakes using hexane solvent extraction. The hexane solvent extraction and recycle system is comprised of a rotocel extractor, a stripper column, a rotary dryer, and a decanter. The recycle system effectively separates the hexane from both the extracted flakes and the hexane-JCO mixture, also known as the miscella. This extraction system consists of the equipment required to separate the hexane from the miscella and wet seed cake ${ }^{17}$ Hexane found in the miscella exiting the rotocel extractor is recovered by stripping it from the JCO. This takes place in the steam-fed stripping column, and hexane is recovered from the hexane-wet flake slurry by evaporating it with steam in the rotary dryer. The water-hexane mixtures are condensed and sent to the decanter, where the water is separated and the hexane is recycled $^{18}$

\section{Section X-100}

The heart of the solvent extraction process, the extractor, must transport the Jatropha curcas flakes as intended but still allow adequate exposure of the flakes to the hexane stream. The extraction of JCO from seed husks begins by feeding ground Jatropha curcas seed flakes into the extractor of choice for this design, a continuous rotocel extractor (X-100). This device resembles a carousel, with walled, annular sectors that lie on a horizontal plane and are slowly rotated by a motor. The cells, which catch and hold the solids, have perforated undersides to allow for solvent drainage. Each cell successively passes through a solids feed area, a series of solvent sprays, a final spray and drainage area, and a solids discharge area. Fresh solvent is supplied to the cell at a rate of $2373 \mathrm{~L} / \mathrm{hr}$, with flakes being supplied at a rate of $2760 \mathrm{~kg} / \mathrm{hr}$. The wet seed cake is then fed into a discharge hopper and sent to the rotary dryer, while the miscella is sent to the stripper for hexane recovery ${ }^{19}$

\section{Section X-101}


The wet seed cake exiting the rotary extractor contains $25-30 \mathrm{wt} \%$ hexanes. To recover this hexane, the cake is fed directly into a rotary dryer (X-101). This dryer consists of a rotating cylindrical shell that is slightly inclined. This incline is specified as having a slope of less than $8 \mathrm{~cm} / \mathrm{m}$ from the horizontal plane. The wet seed cake is fed into the dryer at the high end of the shell, and the dry cake is discharged from the low end. A steam stream flows counter-current to the solids at a rate of $250 \mathrm{~L} / \mathrm{hr}$, thus evaporating the hexane from the seed cake. The bulk solids occupy $10-18 \%$ of the cylinder volume with a residence time of 30 minutes. The dry cake exiting the rotary dryer is then sent to an incinerator, with hexane-water vapors being condensed and collected into a decanter. Heat produced from dry cake incineration is used for heat exchange and to preheat the steam used in this step, providing an added level of efficiency and cost savings ${ }^{20}$

\section{Section T-120}

The miscella leaving the extractor is approximately $66 \mathrm{wt} \%$ hexane. To recover this hexane, the miscella stream is fed into a stripper column (T-120). The stripper of choice is a vertically structured column with eight valve trays, each separated by 12 inches. The column is 22 feet tall and has a diameter of 8.4 inches. There is a four foot head space above the top tray where entrained liquid is removed. Also, a 10- foot space below the bottom tray adds bottoms surge capacity. Two streams enter into the stripper-the miscella and a steam stream used to strip hexane from the JCO within the miscella. The steam stream is fed conditions of $160^{\circ} \mathrm{C}$ and 240 $\mathrm{kPa}$, and the column operates at $160^{\circ} \mathrm{C}$ and $200 \mathrm{kPa}$. The boiling point of the JCO, approximately $870^{\circ} \mathrm{C}$, is far greater than that of hexane, approximately $69^{\circ} \mathrm{C}$, so the hexane stripped JCO flows downward and exists as the bottoms product. This process is highlyeffective, removing approximately $99.99 \%$ of the hexane from the JCO. The resulting hexanesteam mixture is condensed and sent to the decanter, and the JCO is pumped to the appropriate storage tank. All condensed hexane-water mixture is collected into the decanter where, because of a difference in densities, the hexane and water separate. This solution is then heated to remove the hexane, and the water is discharged to the sewer. The vaporized hexane is recycled and directed back to the rotocel extractor ${ }^{21}$

\section{Area 200: Hexane Recovery}

Thus, Area 200 was designed to prevent excessive emission of hexane from the closed systems in Area 100. In addition to increasing plant safety through confining all hexane into a single system, this design also provides the benefit of increased hexane recovery for recycle. Vapors from the extractor, the condensers, the rotocel extractor, and the heaters are all directed to Area 
200 in order to recover any hexane present. The hexane recovery system consists of a vent condenser and a mineral oil stripper-absorber system ${ }^{22}$

\section{Section E-200}

As indicated in the above figure, a vent blower maintains a slight negative pressure on the entire extraction system. If a leak occurs in the system, this pressure will cause air to enter into system, rather than having hexane leak out. The vent vapor from the condensers and process tanks first enters the vent condenser (E-200), and then continues to the mineral oil absorption column ${ }^{23}$

\section{Section T-210}

The mineral oil absorption column (T-210) is a vertically structured column with nine valve trays, each separated by 12 inches. The column is 23 feet tall and has a diameter of 13.9 inches. There is a four foot head space above the top tray where water vapor is allowed to be removed. A 10-foot space below the bottom tray adds bottoms surge capacity. Two streams enter into the absorber-hexane water vapor and a cooled mineral oil stream used to absorb hexane vapors. The vapor streams flow counter current to a stream of cooled mineral oil. Because hexane and mineral oil are both non-polar liquids, they are miscible. The cooler the mineral oil, the higher is hexane's affinity to dissolve into it. The vapor, now free of hexane, exits the top of the column and is safely discharged into the surrounding atmosphere. The mineral oil absorbs the hexane and collects in the bottom of the column. After exiting the bottom of the column, the solution is pumped through a heater, and sent to the stripper column ${ }^{24}$

\section{Section T-211}

The mineral oil stripper column (T-211) is a vertically structured column with nine valve trays, each separated by 12 inches. The column is 23 feet tall and has a diameter of 13.9 inches. There is a four foot head space above the top tray where water vapor is allowed to be removed. A 10foot space below the bottom tray adds bottoms surge capacity. Two streams enter into the stripper - rich oil from the absorber column and steam which is used to strip hexane vapors from the mineral oil. In this column, the heated mineral oil-hexane mixture flows counter current to the steam stream, stripping the hexane from the mineral oil. The hot mineral oil, now free of hexane, is pumped through the oil cooler. The hexane vapor and steam from the top of the column are condensed in the vent condenser and the hexane-water mixture is sent to the decanter V110, where hexane and water are separated and hexane is recycled ${ }^{25}$

\section{Area 300: Treatment and Conversion of Seed Oil to Biodiesel}

Area 300 is comprised of two batch tank reactors and two decanters. The treatment of the crude JCO, an acid-catalyzed transesterification process, reduces the free fatty acid content of Jatropha 
curcas seed oil from $10-20 \%$ to less than $1 \%$, achieved by converting the free fatty acids into biodiesel intermediates. This increases the overall efficiency of the conversion process that follows, where the seed oil is converted into biodiesel. This conversion process is a basecatalyzed transesterification process which occurs in the second batch reactor. Following each batch tank is a decanter which allows the reactor effluents to settle and separate before continuing on to the next step in the process ${ }^{26}$

\section{Section X-300}

JCO enters the first batch reactor tank (X-300) at a pressure of 1 atm and a temperature of $60^{\circ} \mathrm{C}$. For each batch, $6665 \mathrm{~L}$ of JCO is fed into the reactor, where base-catalyzed transesterification takes place. This process requires that the Jatropha curcas seed oil be treated with 0.28 volume/volume of methanol, using $1.43 \%$ volume/volume of sulfuric acid (H2SO4) as a catalyst. The volumes of methanol and sulfuric acid added to the reactor are $2458 \mathrm{~L}$ and $16 \mathrm{~L}$, respectively. Both the methanol and the sulfuric acid enter at atmospheric pressure and $25^{\circ} \mathrm{C}$. This reaction has been optimized to run for 88 minutes at a temperature of $60^{\circ} \mathrm{C}$. The optimized reaction time for each batch is 88 minutes. A head space of approximately $10 \%$ of the overall volume was specified for this reactor, and the size of the reactor tank will be $10500 \mathrm{~L}$. The exit stream contains $9174 \mathrm{~L}$, consisting of $33 \%$ treated JCO and 60\% biodiesel; the remainder is comprised of methanol, sulfuric acid, FFAs, and water ${ }^{27}$

\section{Section V-310}

The exit stream from the reactor flows into the horizontal decanter (V-310), where a gravityinduced settling occurs and two layers separate due to density differences. Two layers that separate in this decanter an organic layer containing JCO, biodiesel, FFAs, and a small amount of sulfuric acid, and a second layer containing water, glycerol, methanol, and the remaining sulfuric acid. The organic layer then proceeds to the second reactor, while the second layer continues for treatment in Area $400^{28}$

\section{Section X-301}

The second reactor (X-301) converts the remaining source oil into biodiesel. This step also neutralizes the sulfuric acid in the treated Jatropha curcas oil stream leaving the reactor. This reactor tank carries out a base-catalyzed transesterification reaction which converts the JCO in the form of mono-, di-, and triglycerides into the final biodiesel product. The purified JCO is added in batches of $9130 \mathrm{~L}$ and treated with 0.20 volume/volume of methanol, approximately $2557 \mathrm{~L}$, and with $0.55 \%$ weight/volume of sodium hydroxide, approximately $85.4 \mathrm{~kg}$. Each batch has an optimized reaction time of 30 minutes and runs at a temperature of $60^{\circ} \mathrm{C}$. 
A headspace of approximately $10 \%$ of the total volume is necessary, with a reactor tank size of 13500 L. The side products in this reactor include glycerin, sodium sulfate, water, and residual soaps. These side products must be treated in Area 400 before a sellable product can be achieved $^{29}$

\section{Section V-311}

The exit stream from the second reactor flows into a second horizontal decanter (V-311) to allow for settling and the separation of layers. Similar to the previous decanter, the organic layer contains mostly biodiesel, with trace amounts of JCO, FFAs, and sodium sulfate. The bottom layer is comprised of glycerol, methanol, sulfuric acid, sodium sulfate, and residual soaps. The biodiesel-rich layer is treated in Area 400 to increase its purity. The bottom layer will also be directed to Area 400 for treatment and methanol recovery 30

\section{Area 400: Biodiesel Treatment and Methanol Recovery}

\section{Section T-400}

Distillation column (T-400) separates methanol from the crude glycerol and vapors vented from Area 300. The separated methanol is recycled back to methanol feed area and is reused in Area 300. The glycerol exiting the bottom of the distillation column is sent to storage and is ready for resale. This column operates with a pressure of $101.3 \mathrm{kPa}$. Crude glycerol enters at a flow rate of 88.3 L/hr. The column contains 10 stages, with the feed entering in the 6 th stage. The specified diameter is six inches and its height is 15 feet, with an optimized reflux ratio of 1.34. The distillate is comprised of $70 \mathrm{~mol} \%$ glycerol, $12.8 \mathrm{~mol} \%$ water, and a remainder of $\mathrm{Na}_{2} \mathrm{SO}_{4}$ salts 31 Section V-410

The glycerol leaving the bottom of the distillation column is collected into a storage tank (V410), which has been specified to hold up to 10 batches. This equates to approximately a 15,000 L capacity ${ }^{32}$

\section{Section T-401}

The counter current liquid-liquid extraction spray column (T-401). This design allows for a pure product with as little waste water as possible. Crude biodiesel from Area 300 enters the bottom of the column and travels upward while contacting water droplets sprayed from the top of the column. The washed biodiesel exits the top of the spray column and is collected into a storage tank (V-411). Waste water exiting the bottom of the column is sent into the drainage system. Washing the biodiesel is extremely important because contaminates such as unreacted methanol and catalyst will damage equipment and burn poorly in diesel engines. This is reflected in the ASTM D6751 biodiesel standards which require the removal of glycerin, catalyst, alcohols, and 
FFAs. In order to wash the biodiesel, water is sprayed into the tower as the dispersed phase. As it travels through the crude biodiesel, the water collects methanol, dissolved salts, and unused catalyst found in the diesel. The total volume of water suggested for washing biodiesel is a standard 2:1 volumetric ratio of water to biodiesel. The column operates with a pressure of 101.3 $\mathrm{kPa}$. Crude biodiesel enters the column at a rate of $897 \mathrm{~L} / \mathrm{hr}$. The column contains 10 stages, with the feed entering in the 6th stage. The diameter is six inches and its height is 15 feet, with an optimized reflux ratio of 1.34. The distillate is comprised of $96.2 \mathrm{~mol} \%$ Jatropha-based biodiesel, $1.78 \mathrm{~mol} \%$ water, and a remainder of methanol. $4.5 .4{ }^{33}$

\section{Section V-411}

The biodiesel exiting the top of the distillation column is collected into a storage tank (V-411), which has been specified to hold up to 10 batches. This equates to approximately a 90,000 L capacity. ${ }^{34}$

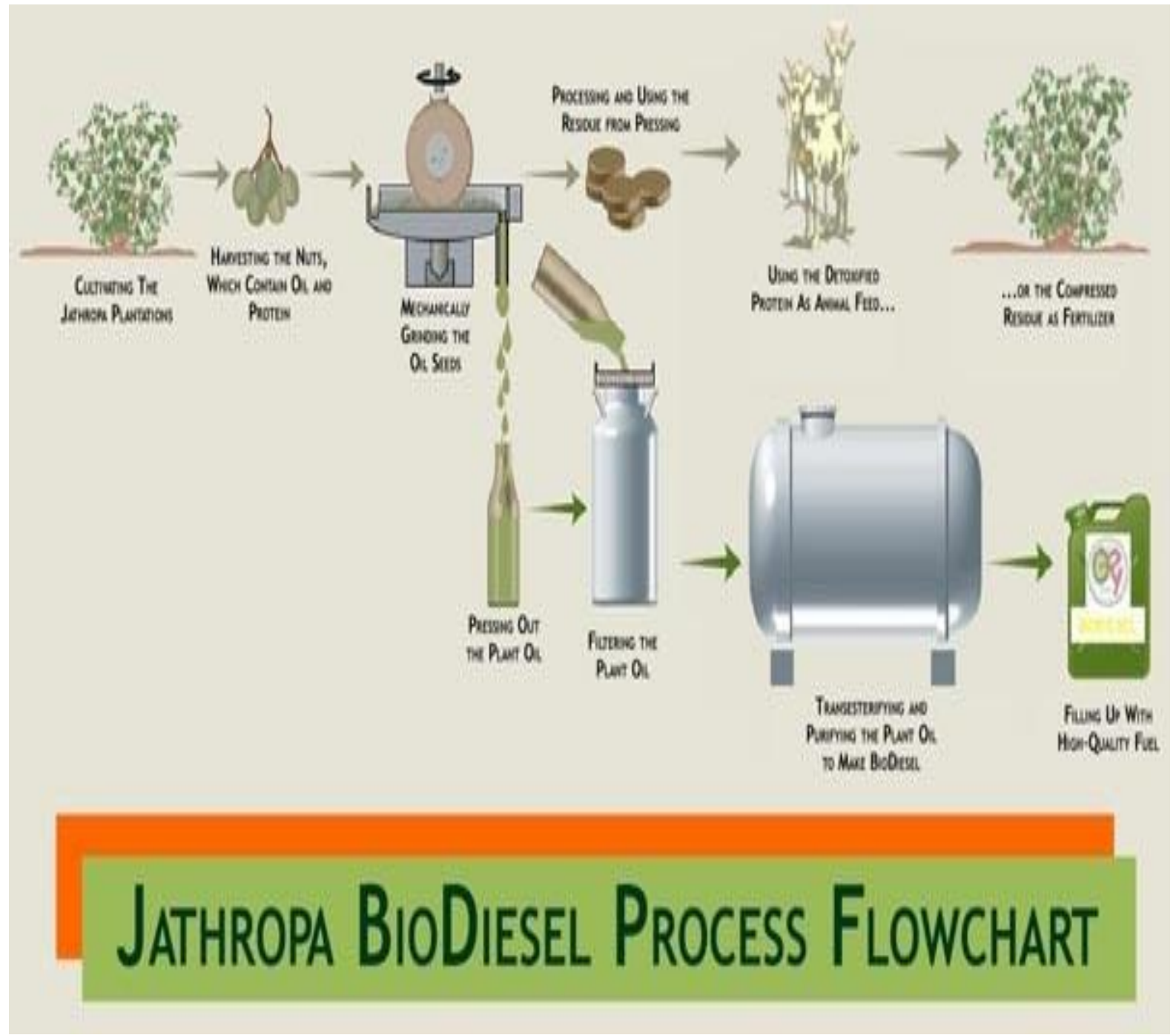




\section{PRODUCTION OF BIO DIESEL USING JATROPHA AS FEEDSTOCK}

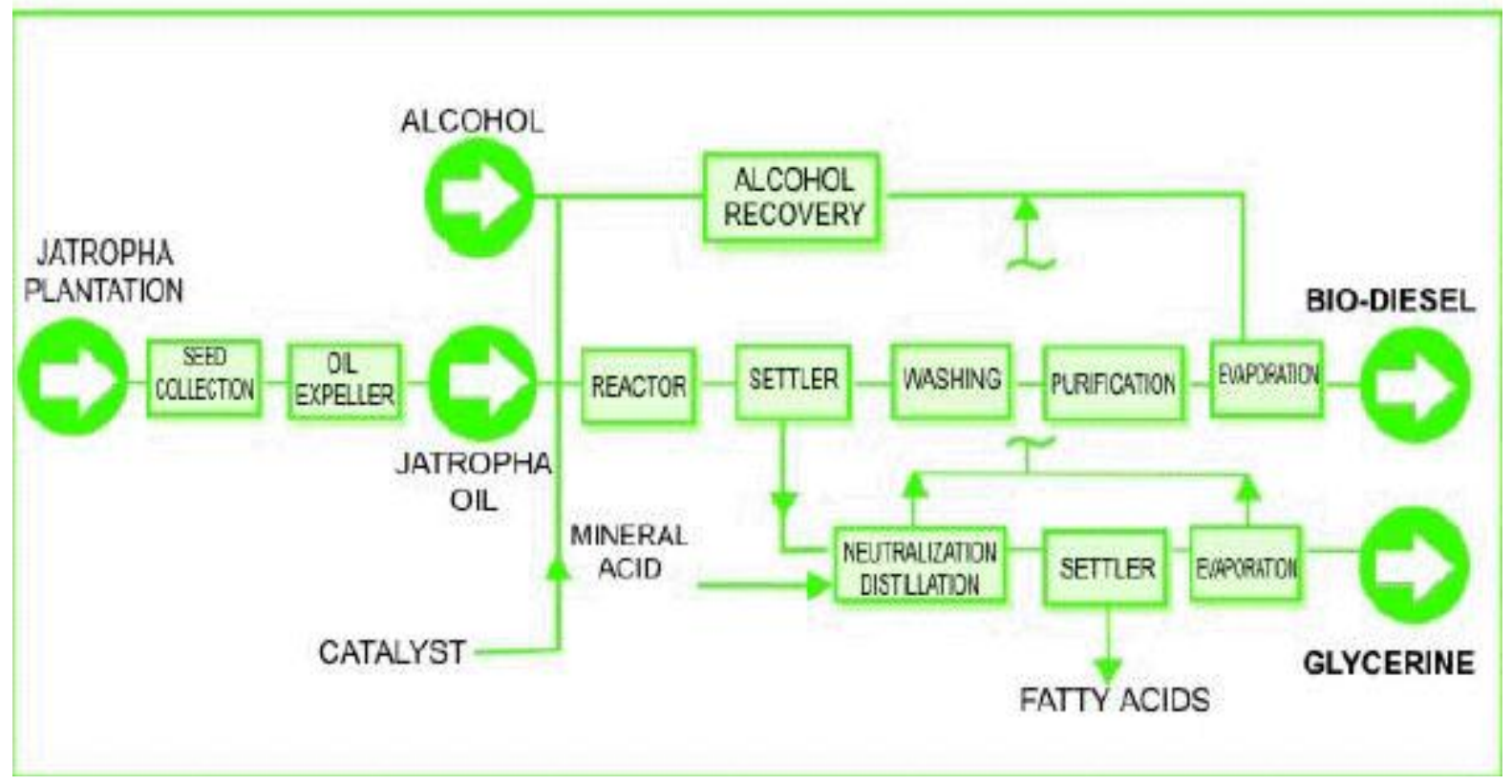

\section{Exploitation of Jatropha (Gubitz, et al, 1998)}

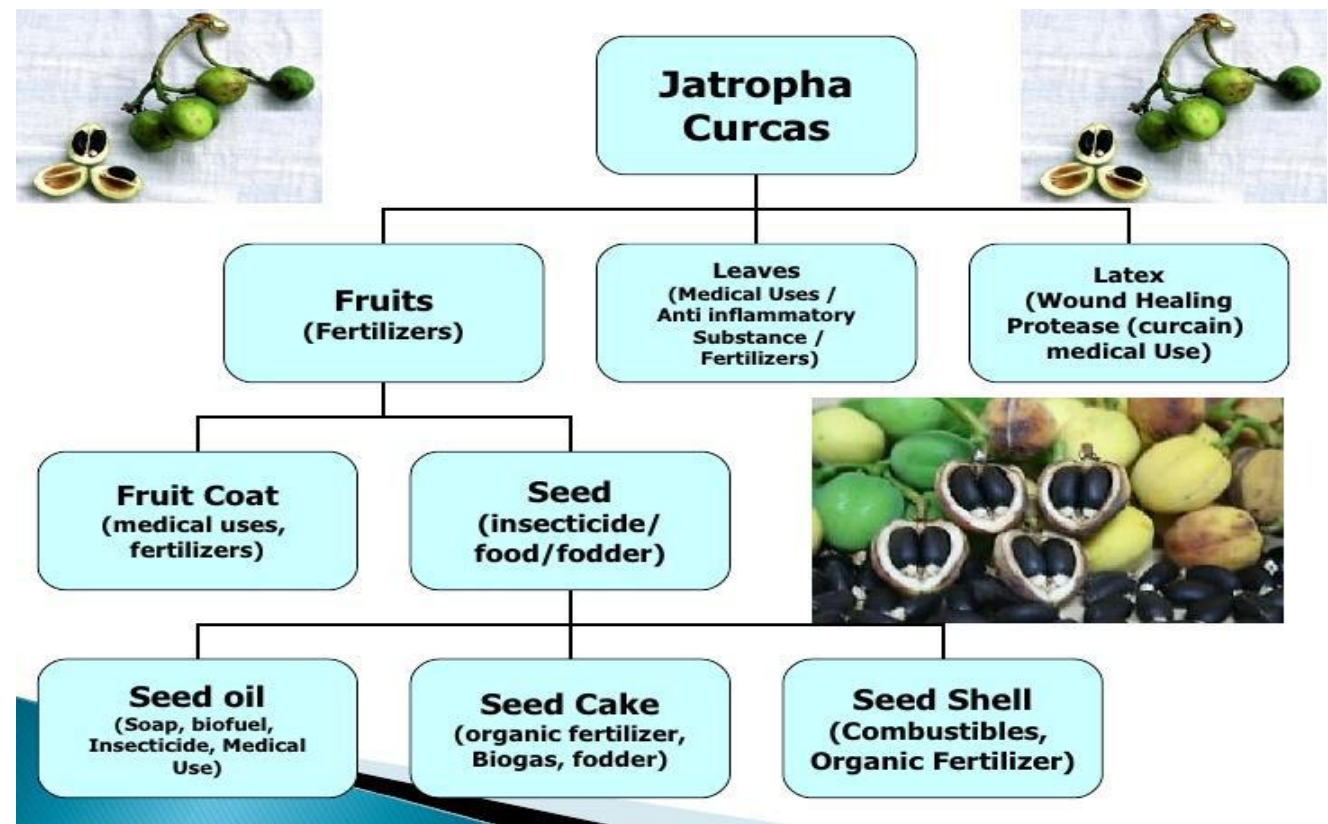

\section{CONCLUSION}

Biodiesel has become more attractive as an alternative to fossil diesel because of its environmental benefits and the fact that it is made from renewable resource. J. curcas L. is a promising source of biodiesel since its seeds contain high amount of oil and the species has good agronomic traits. These properties of $J$. curcas L. have attracted a lot of projects developers. At present, many countries have started cultivating Jatropha trees on large scale, although little is 
known about the positive and negative effects of the large scale production of $J$. curcas L. on ecology as well as other socio-economic situations. There is need to research on the life cycle analysis (LCA) for the biodiesel production from Jatropha curcas L. at small scale and industrial production units particularly in developing countries where there is large scale production of $J$. curcas L. The LCA studies will result in data on the energy balance, the greenhouse gas balance and the land use impact of the $J$. curcas L. biodiesel system.

\section{BIBLIOGRAPHY}

1. Lin, J., Zhou, X., Wang, J., Jiang, P., Tang, K. Purification and characterization of curcin, a toxic lectin from the seed of Jatropha curcas. Preparative Biochemistry and Biotechnology, 2010., 40 (2): 107-118.

2. Achten WMJ, Mathijs E, Verchot L, Singh VP, Aerts R, Muys B Jatropha biodiesel fueling sustainability?. Biofuels, Bioproducts and Biorefining, 2007. 1(4), 283-291

3. Achten WMJ, Verchot L, Franken YJ, Mathijs E, Singh VP, Aerts R, Muys B Jatropha bio-diesel production and use. (a literature review) Biomass and Bioenergy,2008. 32(12), 1063-1084

4. Francis, G., Oliver, J., Sujatha, M.. Non-toxic jatropha plants as a potential multipurpose multi-use oilseed crop. Industrial Crops and Products, 2013 42: 397-401.

5. Nahar, K. and Ozores-Hampton, M. Jatropha: An Alternative Substitute to Fossil Fuel.(IFAS Publication Number HS1193). Gainesville: University of Florida, Institute of Food and Agricultural Sciences. Retrieved (2011).

6. Makkar, H.P.S., Francis, G., Becker, K.. Protein concentrate from Jatropha curcas screwpressed seed cake and toxic and anti-nutritional factors in protein concentrate. Journal of Science of Food and Agriculture 2008,88: 1542-1548.

7. Padgett, Tim ,"The Next Big Biofuel?". Time Magazine. February 6, 2009.

8. Henning, R. K. The Jatropha System An integrated approach of rural development. Rothkreuz 11, D-88138 Weissensberg, Germany(2009),

9. Michael Fitzgerald . "India's Big Plans for Biodiesel". Technology Review. Massachusetts Institute of Technology. Retrieved 2007.

10. Fairless D. "Biofuel: The little shrub that could - maybe". Nature.2007, 449 (7163): 652655.

11. "Jatropha For Biodiesel Figures - REUK.co.uk". www.reuk.co.uk. 
12. Barta, Patrick . "Jatropha Plant Gains Steam In Global Race for Biofuels" 2007,-- via wWw.wsj.com.

13. World Agroforestry Centre When oil grows on trees Archived 2009-04-10 at the Wayback Machine.

14. King AJ, He W, Cuevas JA, Freudenberger, Ramiaramanana D and Graham IA. . Potential of Jatropha curcas as a source of renewable oil and animal feed: Review paper. Journal of Experimental Botany.,2009,10,.1093

15. Bayer CropScience Press Release, . Jatropha - This particular oil well holds a lot of future promise Archived,2008

16. Grass M.,Jatropha curcas L.: Visions and Realities. Journal of Agriculture and Rural Development in the tropics and Subtropics Volume 110, No. 1, 2009, pages 29-38.

17. Lozano J. A. D. Botanical Characteristics of Jatropha curcas L. Jatropha Project in Mexico.2007.

18. DEGJSP, 'Farmers Handbook: advice on growing Jatropha curcas in East Africa'. DEG Jatropha support Program (DEGJSP). June 2012. .

19. Oliveira H. de, A. C. P. Juhasz, S. Pimenta, B. O. Soares, Batista Morais de Lourdes, D., Rabello, Floral biology and artificial .2009.

20. Polinization in physic nut in the north of Minas Gerais state, Brazil [Biologia floral e polinizacao artificial de pinhao-manso no norte de Minas Gerais] Pesquisa Agropecuaria Brasileira, 44(9): 1073-1077 (in Portuguese)

21. DNA Res., . "Sequence Analysis of the Genome of an Oil-Bearing Tree, Jatropha curcas L".Oxford Journals,

22. 5 Juhász, S. Pimenta, B.O. Soares, Batista Morais de Lourdes, D., Rabello, H. de Oliveira . Floral biology and artificial polinization in physic nut in the north of Minas Gerais state, Brazil [Biologia floral e polinização artificial de pinhão-manso no norte de Minas Gerais] Pesquisa Agropecuaria Brasileira, 2009, 44(9): 1073-1077 (in Portuguese)

23. "Generative propagation of Jatropha curcas L. on Kalahari Sand." in The Jatropha Journal. Archived November 15, 2007, at the Wayback Machine.

24. Guzman (De), Lucille Elna Parreno and Annalissa Lappay Aquino; Seed Characteristics and Storage Behavior of Physic Nut (Jatropha curcas L.); Philippine Journal of Crop Science,2009, v.34, n.1, p.13-2 
25. Silva (da), Laércio Junio et al.; The Effect of Fruit Maturity on the Physiological Quality and Conservation of Jatropha curcas Seeds; Revista Ciência Agronômica,2017, v. 48, n. 3, p. 487-495; /

26. Heller, Joachim; Physic Nut, Jatropha curcas L. - Promoting the Conservation and Use of Underutilized and Neglected Crops, 1996, p.31; -03.

27. Fairless D. (2007). "Biofuel: The little shrub that could - maybe". Nature,2007,. 449.

28. Barta, Patrick "Jatropha Plant Gains Steam In Global Race for Biofuels" ,2007

29. Enviro.aero Air New Zealand jatropha flight,2008

30. Satish Lele, 2007. Developmentof the Jatropha cultivation and bio-fuel production system.

31. Abreu,F.,Alternative by-products from Jatropha. , 2008

32. McKendry, P. Energy production from biomass (part 1): overview of biomass. Bioresource Technology, 2002,Vol. 83, pp. 37- 46. 